The Formation and Protection of Property Rights among the Southern Kwakiutl Indians

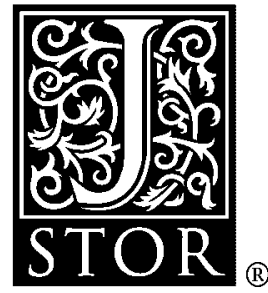

\author{
D. Bruce Johnsen
}

The Journal of Legal Studies, Vol. 15, No. 1 (Jan., 1986), 41-67.

Stable URL:

http://links.jstor.org/sici?sici=0047-2530\%28198601\%2915\%3A1\%3C41\%3ATFAPOP\%3E2.0.CO\%3B2-P

The Journal of Legal Studies is currently published by The University of Chicago Press.

Your use of the JSTOR archive indicates your acceptance of JSTOR's Terms and Conditions of Use, available at http://www.jstor.org/about/terms.html. JSTOR's Terms and Conditions of Use provides, in part, that unless you have obtained prior permission, you may not download an entire issue of a journal or multiple copies of articles, and you may use content in the JSTOR archive only for your personal, non-commercial use.

Please contact the publisher regarding any further use of this work. Publisher contact information may be obtained at http://www.jstor.org/journals/ucpress.html.

Each copy of any part of a JSTOR transmission must contain the same copyright notice that appears on the screen or printed page of such transmission.

JSTOR is an independent not-for-profit organization dedicated to creating and preserving a digital archive of scholarly journals. For more information regarding JSTOR, please contact support@ jstor.org. 


\title{
THE FORMATION AND PROTECTION OF PROPERTY RIGHTS AMONG THE SOUTHERN KWAKIUTL INDIANS
}

\author{
D. BRUCE JOHNSEN*
}

\section{INTRODUCTION}

$\mathrm{T}$ HIS essay is about economics, anthropology, and law. I use the historical context of the Southern Kwakiutl (kwäkē[y]üd $\left.{ }^{2} l\right)$ Indians following contact with European civilization to test the relevance of economic theory to primitive societies. When recorded contact with the Southern Kwakiutl was first made along the north Pacific coast of North America, they were found to have established a curious reciprocal exchange system called potlatching. Since that time, potlatching has received considerable attention from ethnographers and anthropologists but virtually none from economists. I argue in this essay that the Southern Kwakiutl Indians used the potlatch system to maintain exclusive property rights in their most important capital asset and main source of wealth, the salmon fishery. In so doing, I demonstrate that recognizing the structure of property rights as endogenous - that is, at the discretion of the participants-greatly enhances our understanding of primitive societies. In general, economic theory has a great deal of power in explaining the institutions and behavior of primitive man.

The Kwakiutl potlatch has been described as "the ostentatious and dramatic distribution of property by the holder of a fixed, ranked and

* Visiting Assistant Professor of Management, Business and Public Policy Group, Texas A\&M University. This paper was written while I was studying as a John M. Olin Fellow in law and economics at the Law and Economics Center of Emory University Law School. I would like to thank Peter Aranson, Yoram Barzel, Bill Carney, Price Fishback, Doug North, and Mark Plummer for helpful comments and encouragement on earlier drafts. Special thanks go to David Haddock. I would also like to thank Tarver Rountree for motivating my work in the area of law and anthropology; I have found it both interesting and worthwhile. An earlier version of this paper was presented at the 1983 annual meeting of the Southern Economic Association.

[Journal of Legal Studies, vol. XV (January 1986)]

(C) 1986 by The University of Chicago. All rights reserved. 0047-2530/86/1501-0002\$01.50 
named social position, to other position holders."1 Potlatching, then, was a formalized method of redistributing wealth among members of Kwakiutl society. This system of wealth redistribution is consistent with individual and social wealth maximization, given the exogenous geographic and intertemporal fluctuations in salmon output experienced by the Southern Kwakiutl. To prevent overexploitation of the salmon fishery the various Kwakiutl kinship groups recognized exclusive territorial fishing rights among themselves. ${ }^{2}$ Although the private property rights structure led to an increase in the total wealth of Kwakiutl society, it also generated fluctuations in each group's output relative to the alternative-a common property rights structure. Prior to the development of potlatching, as one kinship group's marginal labor product fell due to a poor fishing season, the tendency increased for its members to encroach on the territory of another kinship group whose marginal labor product was higher. When discovered, the encroachers were invariably met with violence by the incumbents, and, understanding this, the would-be encroachers often came with violent intentions of their own. According to the historical record, in prehistoric and early contact times (as opposed to the late contact period), bloody wars were often fought over possession of fine salmon streams with entire kinship groups sometimes being exterminated in the process.

In order to provide the incentive for would-be encroachers to recognize exclusive property rights, and thus to prevent violence, those Kwakiutl kinship groups whose fishing seasons were relatively successful transferred wealth through the potlatch system to those groups whose seasons were not so successful. To discourage free riding on the system Kwakiutl ideology revered social prestige acquired through the accumulation of wealth and its distribution at potlatches. The kinship group that attempted to free ride by holding few or meager potlatches would have found itself descending in the potlatch ranking, ultimately leading to a reduction in the value of potlatch gifts it later received from other kinship groups. In this sense, not only did potlatching promote exclusive property rights but, by smoothing intertemporal variations in the opportunity cost of encroachment, it also forestalled socially wasteful, violent conflict. Although potlatching thereby served as a form of insurance, the relevant constraint in its adoption and survival was the cost of enforcing exclusive property

\footnotetext{
${ }^{1}$ Helen Codere, Fighting with Property: A Study of Kwakiutl Potlatching and Warfare, $1792-1930$, at 63 (1950).

${ }^{2}$ Each kinship group thereby became more sensitive to the long-run decrease in catch that follows short-run overfishing of the parent stock of the stream.
} 
rights rather than simple risk aversion as at least one anthropologist has suggested.

The study of primitive man has traditionally been considered the exclusive work of anthropologists, who have questioned whether economic theory can explain human behavior in primitive societies because they lack important economic institutions, such as organized exchange markets and monetary systems for which the tools of economic theory are specifically designed. ${ }^{3}$ Indeed, economics has much to say about these institutions, but its relevance and scope are not so limited. To quote Richard Posner on this subject, "It is a sterile debate. The contending groups share an excessively narrow view of what is economic." 4 Economic theory requires neither organized exchange markets nor monetary systems; it requires only that man live in a world of scarcity, forcing him to make marginal trade-offs between alternatives. This condition seems inescapable, especially for primitive man.

In studying primitive societies anthropologists often assert a fundamental distinction between formal law and social mores. ${ }^{5}$ Here again economists and anthropologists are in discord. As a positive science, economic theory explains human behavior on the basis of a well-defined set of behavioral postulates or hypotheses. But because economists are restricted to ordinal measurement of the relevant magnitudes, the testable implications of their hypotheses are restricted to statements about how human behavior changes in response to changing constraints. Formal law is just one of several constraints on human behavior including, among others, environmental and ideological constraints. While legal constraints consist of coercive sanctions imposed by the state on socially undesirable behavior, ideological constraints consist, at least in part, of social mores backed by social disapproval and ingrained patterns of guilt or shame imposed by the group when behavior is contrary to the prevailing ideology. ${ }^{6}$ Since both types of constraints affect behavior, the distinction made by anthropologists between formal law and social mores is of little theoretical significance to the economist.

${ }^{3}$ George Dalton, Economic Theory and Primitive Society, 63 Am. Anthropologist 1 (1961).

${ }^{4}$ Richard A. Posner, A Theory of Primitive Society, with Special Reference to Primitive Law, 23 J. Law \& Econ. 1, 2 (1980).

${ }^{5}$ See, for example, Bronislaw Malinowski, Crime and Custom in Savage Society (1976); see also Sally Falk-Moore, Law as Process: An Anthropological Approach (1978).

${ }^{6}$ De gustibus non disputandum est. Conformity to the prevailing ideology can be defined as an economic good. The only relevant differences between law and social mores are the methods by which they are enforced and their observability or measurability to the social scientist. 
The remainder of this essay develops and tests my explanation of Kwakiutl potlatching as an institution designed to protect private property rights. Such an analysis would be incomplete without at least an elementary description of the salient features of Kwakiutl culture. This description follows immediately in Section II, where I first provide a general history of the Southern Kwakiutl and then describe four basic areas of Kwakiutl culture-social order, production, warfare, and potlatching. Since contact with European civilization was an exogenous constraint on the Southern Kwakiutl that will provide a basis for testing my hypothesis, I note when appropriate its influence on Kwakiutl culture.

Next, in Section III, I discuss the leading anthropological explanations of the Kwakiutl potlatch by Codere ${ }^{7}$ and Piddocke. ${ }^{8}$ Codere explains potlatching as an alternative to warfare in the Kwakiutl's limitless pursuit of social prestige, although she does not explain why social prestige was important to the Kwakiutl or why it manifested itself through potlatching. Piddocke, the main proponent of what anthropologists describe as the "functional approach" to potlatching, ${ }^{9}$ explains the potlatch as a method by which Kwakiutl kinship groups insured against local variations in resource productivity. By failing to recognize the structure of property rights as endogenous, however, Piddocke misidentifies the relevant constraints.

In Section IV, I develop my explanation of Kwakiutl potlatching based on property rights protection. In the process I discuss and borrow freely from the growing property rights literature. To some extent my explanation integrates the explanations of Codere and Piddocke. I demonstrate, however, that the implications of contact with European civilization derived from Piddocke's explanation conflict with those of my own, and that my explanation is consistent with the facts while Piddocke's is not. I also support my analysis with some of the rich, although casual, evidence found in the historical record.

Finally, in Section V, I make some concluding comments and briefly discuss the importance of reciprocity relations in primitive societies. According to my analysis reciprocity is a method of assuring exclusive property rights in the absence of enforcement by a third party-the statewith comparative advantage in violence.

${ }^{7}$ Codere, supra note 1.

${ }^{8}$ Stuart Piddocke, The Potlatch System of the Southern Kwakiutl: A New Perspective, in Economic Anthropology: Readings in Theory and Analysis 283 (Edward E. LeClair, Jr., \& Harold K. Schneider eds. 1968).

${ }^{9}$ For example, Martin Orans, Domesticating the Functional Dragon: An Analysis of Piddocke's Potlatch, 77 Am. Anthropologist 312 (1974). 


\section{Culture of the Southern Kwakiutl}

\section{A. General History}

The Southern Kwakiutl Indians lived along the inland waterways of Queen Charlotte Sound between the northeastern tip of Vancouver Island and the adjacent mainland of British Columbia, Canada. The region is heavily forested, with rugged mountains descending abruptly to the sea. Countless rivers and streams flow from the mountains, providing excellent spawning habitat for several species of salmon. ${ }^{10}$ By harvesting the often abundant salmon during their summer migration upstream to spawn, the Southern Kwakiutl normally secured sufficient food stocks to sustain themselves through the remainder of the year.

The Southern Kwakiutl are just one of several dialectic groups that inhabited the north Pacific coast of North America. In spite of their diverse origins and language, these groups shared many common characteristics, most notably their dependence on salmon as a staple and their preoccupation with potlatching. This essay focuses primarily on the Southern Kwakiutl, as they are the subject of the greatest share of the historical record of the north Pacific coast Indians. ${ }^{11}$ When necessary, however, I draw inferences about the Southern Kwakiutl from their neighbors to the north - the Tlingit, the Tsimshian, and the Bella Coolaand to the south-the Nootka and the Coast Salish.

Recorded contact with the Southern Kwakiutl was first made by Admiral Vancouver when he explored and mapped Queen Charlotte Sound in $1792 .{ }^{12}$ For many years prior to that time, Russian, Spanish, English, and American ships had explored the coast trading with the various Indian groups they encountered for sea otter and other fur pelts. Before long, intense competition for sea otter pelts developed between these flagships, a situation the Indians are reported to have exploited to their distinct advantage.$^{13}$ Eventually the Hudson's Bay Company established permanent trading posts along the coast at Fort Langley (1827), Fort Simpson (1834), Fort McLoughlin (1834), ${ }^{14}$ and Fort Rupert (1834) in the center of Southern Kwakiutl territory. ${ }^{15}$ Following construction of these forts the British succeeded in dominating trade in the region.

${ }^{10}$ These included spring, coho, sockeye, pink, and chum salmon. See, for example, Philip Drucker, Cultures of the North Pacific Coast 5 (1965).

${ }^{11}$ Much of the historical record of the Southern Kwakiutl was compiled by the famous ethnographer Franz Boas. See, generally, Franz Boas, Kwakiutl Ethnography (1966).

12 Codere, supra note 1 , at 1.

${ }^{13}$ Philip Drucker, Indians of the Northwest Coast 19-23 (1955).

${ }^{14} \mathrm{Id}$. at 22.

15 Codere, supra note 1 , at 23. 
During the prehistoric and early contact period the Indians of the north Pacific coast were very warlike and possessive of their territories. In several cases they attacked and successfully destroyed trading vessels ${ }^{16}$ and even fortified trading posts. ${ }^{17}$ In prehistoric and early contact times the Indians also fought among themselves over trading rights and valuable natural resources. Wars were often waged to annihilate an entire group to gain possession of its fine salmon stream, to seek revenge for prior wrongs, or simply to pillage and plunder. ${ }^{18}$ As European contact and trade increased, however, the incidence of warfare and violence among the Indians declined. No doubt the "Pax Britannica," 19 a prohibition by the Crown on all Indian warfare and violence, either entirely caused or strongly reinforced this trend. The Pax Britannica is said to have been rigidly enforced "on a scale that was intended to teach a lesson and enforce European ideas about law and order in an absolute way." 20 In several cases royal gunboats leveled entire Kwakiutl villages as punishment for the death of one or two Indians. ${ }^{21}$

Throughout the second half of the nineteenth century, royal Indian agents and missionaries increasingly disapproved of potlatching, which they saw as a hindrance to the progress, civilization, and Christianization of the Southern Kwakiutl. Canadian authorities ultimately blamed potlatching for the Kwakiutl's declining material condition in the late nineteenth and early twentieth centuries, claiming it led them to dissipate $^{22}$ and squander their wealth and prevented them from securing "continuous wholesome food." ${ }^{23}$ In spite of legal prohibitions on potlatching imposed by Canadian authorities through the Indian Act, it continued

16 Drucker, supra note 10, at 192.

17 Drucker writes: "A demonstration ... of their belief in the importance of their monopolistic trade rights is reported to have been made by the Chilkat Tlingit in 1852. This group sent a war party nearly three hundred miles inland on a mission, successfully carried out, of capturing and destroying the Hudson's Bay Company's post of Fort Selkirk, at the junction of the Lewes and Pelly rivers. The captured personnel of the post were not massacred, but humanely released with the stern warning, however, that they should stay out of Chilkat trading territory." Drucker, supra note 13, at 22.

${ }^{18}$ For example, Drucker, supra note 10, at 19; Boas, supra note 11, at 105-19; and Morris Swadesh, Motivations in Nootka Warfare, 4 Sw. J. Anthropology 76 (1948).

19 Drucker, supra note 10, at 82, 111, 226. Drucker gives no date for the Pax Britannica, however.

${ }^{20}$ Codere, supra note 1 , at 113.

21 Id. at 114-17.

${ }^{22}$ In economics, of course, the term "dissipate" implies a social loss as opposed to an individual loss. Since, in most cases, potlatch goods were transferred, little dissipation occurred in the economic sense.

${ }^{23}$ Codere, supra note 1, at 82 (citing Blenkinsop, Canadian Annual Report on Indian Affairs (1881), at 48). 
among the Southern Kwakiutl. ${ }^{24}$ Not until the 1920s was formal legal action taken against potlatching, and even then few individuals appear to have been prosecuted. ${ }^{25}$

There is general consensus among ethnographers that Kwakiutl population during precontact times was large enough to press the limits of the environment, in some cases leading to local starvation. ${ }^{26}$ As is normally reported in historic accounts of contact between American Indians and European civilization, white man's diseases-smallpox, measles, and syphilis-took a heavy toll on the Southern Kwakiutl. ${ }^{27}$ One census claims a 90 percent reduction in Kwakiutl population, from 23,587 to 2,264 between 1841 and $1883 .{ }^{28}$ Although there is some reason to question the accuracy of this account, there is, nevertheless, ample evidence to indicate that the Kwakiutl experienced significant population decline as European contact increased. Of course, European contact also brought extensive trade and, consequently, increases in total Kwakiutl wealth. The combination of the effects of trade and population decline caused a steady increase in per capita Kwakiutl wealth throughout the early contact period. Rising per capita wealth was accompanied by an observed increase in the frequency and intensity of potlatching. ${ }^{29}$

\section{B. Social Order}

The Southern Kwakiutl were divided into twenty-eight autonomous tribal units whose relationship was delineated by the potlatch system. Each tribal unit consisted of anywhere from three to seven kinship groups, called numayms (noo 'my ums). Franz Boas identified the numaym as the fundamental social unit and considered the tribe merely as the "effect of congregation at one place of a number of . . ." numayms. ${ }^{30}$ This characterization of the tribe and numaym probably arose from the numayms' seasonal pattern of intraregional migration. During the production-oriented summer months each numaym occupied and exploited a specific territory asserted to have been its place of ancestral origin or a place captured by its ancestors in war. During the leisure-oriented winter

${ }^{24}$ Id. at 87 n.36.

25 Potlatching then went underground and became a small private affair with a written record of potlatch gifts substituting for public witnesses.

${ }^{26}$ Piddocke, supra note 8, at 284-85.

${ }^{27}$ Id. at 284-87; and Drucker, supra note 10, at 64, 197-98.

${ }^{28}$ Codere, supra note 1 , at 50.

29 Id. at 89-97.

${ }^{30}$ Franz Boas, The Social Organization of the Kwakiutl, 22 Am. Anthropologist 111, 111 (1927). 
months, on the other hand, the numayms of a tribe congregated at a coastal village where each numaym lived communally in a large cedar lodge. These villages are said to have been judiciously located and heavily fortified in prehistoric and early contact times to minimize the likelihood of a successful enemy attack. ${ }^{31}$

It was during the unproductive winter months that potlatches were most often held. The numaym lodges, each of which contained a large communal space, were ideally suited for such gatherings. While Boas characterized the numaym as the fundamental social unit, he noted the importance of the tribe as a basis for ranking and matching the numayms of different tribes according to social prestige. ${ }^{32}$ Status ranking and matching were pervasive attributes of Kwakiutl society, with social prestige a function of the group's success at potlatching. Not only were all tribes ranked according to social prestige, but within a tribe the numayms were also ranked, as were certain individual members within each numaym. The numaym leader or chief held the top-ranked position within the numaym, and his rank relative to other numaym chiefs was determined by the relative rank between their respective numayms. The leader of the highest ranking numaym within a tribe was considered the chief of that tribe.

\section{Production}

Salmon were the staple of most tribes of the Southern Kwakiutl and were harvested with often elaborate fish weirs and traps, or with nets, harpoons, and spears during their summer spawning migration upstream from the sea. ${ }^{33}$ Those salmon not harvested were left to continue their migration to the upper reaches of the stream where they would spawn and die. As today, after hatching the immature salmon gradually made their way to the sea. In two to four years, depending on the species, the mature salmon migrated back to their place of birth to spawn and die like their ancestors, thus completing the life cycle. The size of a particular salmon "run" depended on the success of the previous generation at spawning and the success of the current generation at surviving to maturity. These success rates were influenced by water levels and temperatures during

${ }^{31}$ Drucker, supra note 10 , at 81.

${ }^{32}$ Boas, supra note 30, at 115.

${ }^{33}$ Several Kwakiutl numayms inhabiting the islands of Queen Charlotte Sound derived their main food supply from halibut fishing. These numayms held private fishing rights in water over designated halibut banks. The extent of the private areas was determined by the lines of sight of various fixed points on the horizon. 
spawning, permeability of stream beds, salinity, and fishing pressure, among other things. ${ }^{34}$ Any of these variables could adversely affect the size of a particular salmon run, which would in turn affect the size of later generations of the same run. Consequently, even though most streams supported runs of several species of salmon, the total number of salmon entering a stream during the summer was often subject to considerable yearly variation. ${ }^{35}$

Perhaps in response to observed yearly variations in the size of salmon runs, the numaym priest conducted the First Salmon Rite immediately following the first catch of the summer. The Kwakiutl believed the spirit of the salmon to be immortal, and that it voluntarily sacrificed its body for the benefit of man. If the salmon spirit was offended, the salmon run might not return full force in following years. "Throughout the rite there was constant reference to the run and its continuance, and the first fish was usually placed with its head pointing upstream so the rest of the salmon would continue upstream and not turn back to the sea." 36 The salmon was then ceremoniously cooked by the priest and each participant given a sacramental taste. Following this ritual the numaym members would begin fishing, but not without restrictions by the chief on the number of salmon taken and their allocation. ${ }^{37}$

As already noted, with the advent of trade, sea otter and other fur pelts became commercially important. ${ }^{38}$ Shortly after trade began, however, the once abundant sea otter was hunted nearly to extinction. ${ }^{39}$ As European contact increased salmon became a commercial good, especially following construction of local canning factories. Also an important commercial good was eulachen oil, obtained by boiling the fish of the same name whose oil content was said to be so high they could be burned as candles.

The bulk of the year's production occurred during the summer months when the weather was good and the salmon were running. At this time the numayms occupied and exploited their ancestral fishing and hunting ter-

${ }^{34}$ Piddocke, supra note 8 , at 286.

35 Id. at 287.

36 Drucker, supra note 10, at 95 . Drucker seems to indicate that the Kwakiutl were well aware of the relationship between the size of salmon runs through time.

37 Id.

38 Piddocke, supra note 8, at 291.

39 See Drucker, supra note 13 , at 22 . Without knowing more about the habits of halibut and sea otters, I find it odd that private property rights should exist in halibut fishing waters but not in sea otter hunting waters. According to my analysis, we should expect to find that halibut tended to stay within a much smaller geographic area than sea otters. That halibut fishing was done over designated halibut banks suggests this was in fact the case. 
ritories. Each numaym, through its chief, asserted exclusive ownership rights to its ancestral lands. Trespass by outsiders was a frequent cause for conflict, often ending in the death of the trespasser. ${ }^{40}$ In the latter portion of the nineteenth century Canadian authorities turned many Kwakiutl fishing stations into Indian fishing reserves, which were thereafter protected against white encroachment. ${ }^{41}$ There is no evidence, however, that these fishing reserves were protected from encroachment by other Indians. ${ }^{42}$

According to Boas, "The numayms of all the tribes . . . all own rivers." 43 This statement seems to indicate that rivers and streams were owned in their entirety by a single numaym, an inference supported by the following account of property rights among the Tlingit Indians of southeast Alaska:

The question of boundaries gave little trouble. The salmon streams when small were owned throughout their length, and when large, as we have seen, the question of ownership did not enter. The hunting grounds usually consisted of the watershed of the streams or valleys well enclosed by hills or high mountains. In Klukwan the clans divided the mountain slopes for goat hunting by the Ganaxtedi taking the valley above the village and the Kagwantan taking the valley below the village. The other two clans had valleys in the more distant tributaries of the main stream. Berry, root, and clover patches were small and often possessed by single houses. The same was true of rocks for sealing. ${ }^{44}$

A numaym's exclusive ownership rights to hunting, gathering, and fishing grounds were vested in its chief and manifested in his ceremonial privileges, names, and crests. The chief directed productive activities and allocated a customary share of the output to each member of the numaym. ${ }^{45}$ The Coast Salish Indians, neighbors of the Kwakiutl to the south, believed that the chief's privileges, names, and crests endowed him with supernatural powers that helped him succeed as a resource manager. According to Salish ideology, the more successful wealthier

40 Boas, supra note 11 , at 36.

${ }^{41}$ Codere, supra note 1 , at 25-26.

42 Id. This fact is critical to my analysis, since if private property rights in fishing and hunting territories were protected against encroachment from other numayms, there would have been little use for potlatching to protect property rights. Even if the Indians did have nominal access to the Canadian legal system to prosecute trespass, however, it is doubtful whether they could have exercised those rights effectively.

${ }^{43}$ Boas, supra note 11, at 36.

44 Kalervo Oberg, The Social Economy of the Tlingit Indians 57 (1937).

${ }^{45}$ Swadesh, supra note 18 , at 76,78 ; and Drucker, supra note 10 , at 48 . Presumably, the customary share was related to that member's marginal productivity. 
chiefs possessed secret knowledge of "good" behavior, while the lesser chiefs were "without advice." 46

The Southern Kwakiutl demonstrated a tendency for standardization in production based on measurement in hand lengths. Food storage boxes were standard in size, as were many implements, tools, and capital equipment, such as canoes. The Kwakiutl propensity for standardization can also be seen in their ready adoption of the Hudson's Bay blanket as a medium of exchange and predominant potlatch gift following contact and trade with Europeans. This tendency toward standardization may have been an adaptation to potlatching, since all of these goods were given as potlatch gifts and counted in the wealth transfer. Standardization undoubtedly allowed easy comparison of the gifts given by potlatch rivals in evaluating generosity.

\section{Warfare}

Historical accounts of warfare contradict one another over the purpose of violent conflict among the Southern Kwakiutl. Codere-whose work is concerned primarily with the late nineteenth and early twentieth centuries, when Canadian authority was firmly established-claims the Kwakiutl were generally peaceful people, with violent acts perpetrated mostly by "professionals" attempting to establish a reputation for atrocity and ruthlessness. ${ }^{47}$ The main purpose for violent acts, according to Codere, was to steal the power of the victim as represented by his ceremonial privileges, names, and crests $;^{48}$ to avenge an insult or transgression; or to get someone to die for a dead friend or relative (whose death may have been accidental). Most important, Codere argues that war was never waged among the Southern Kwakiutl for material gain or to obtain land or fishing rights. In Codere's view the overriding purpose for violence was to increase one's social prestige. Oddly enough, however, and very unlike the Indians of the interior, the Kwakiutl glorified a warrior not for his courage or bravery but only for his success at killing. ${ }^{49}$ Consequently, attacks were often made on unsuspecting and defenseless victims ${ }^{50}$ with the element of surprise weighing heavily in the aggressor's decision whether or not to attack.

\footnotetext{
46 Wayne Suttles, Affinal Ties, Subsistence, and Prestige among the Coast Salish, 62 Am. Anthropologist 296, 301, 303 (1960).

${ }^{47}$ Codere, supra note 1 , at 106.

48 Id. at 103.

49 Id. at 106.

50 Boas, supra note 11, at 110 .
} 
Early accounts of Kwakiutl warfare contradict Codere's assertion that wars were never waged to gain possession of salmon streams. According to Boas, "the war records tell us of whole tribes that were practically annihilated . . .,"51 and Drucker writes: "Wars were carried on to secure booty, to capture slaves, and very often to gain possession of basic resources-lands of economic importance." 52 These early accounts leave little doubt that, at one time, war designed to annihilate another group in order to obtain its fishing and hunting territories was commonplace. As contact increased, however, Kwakiutl warfare seems to have been increasingly directed toward non-Kwakiutl groups as opposed to other Kwakiutl groups. With this trend came a tendency on the part of intended victims to offer protection payments to those who threatened attack. For example, Boas recounts the tale of a man "who makes war against the chiefs of foreign tribes and, by the mere threat of an attack, induces them to give him their daughters." 53

The Nootka Indians, the southern neighbors of the Kwakiutl on the western shore of Vancouver Island, had a reputation for being more warlike than the other Indian groups of the north Pacific coast. They also appear to have continued their warlike ways later into the contact period than did most groups. ${ }^{54}$ The Nootka obtained a large portion of their food supply from whaling in addition to salmon fishing. In discussing nine war narratives of the Nootka, Swadesh finds the primary motivation for extensive intragroup warfare to be the taking of land and fishing rights. ${ }^{55}$ As with the Kwakiutl, however, in many cases the Nootka gave gifts or held potlatches to appease their would-be attackers. Swadesh also notes that wars designed to take land and fishing rights away from other tribes or kinship groups required the annihilation of the entire group, a project incurring substantial effort and loss of life. Consequently, unless the potential victims were relatively weak, the project was unlikely to be undertaken. ${ }^{56}$

As previously noted, the incidence of violent conflict among the Southern Kwakiutl declined as contact with European civilization increased. Sanctions against violence were rigidly enforced by Canadian authorities, unlike sanctions against potlatching, which were poorly enforced, if at all.

si Id. at 47.

52 Drucker, supra note 10 , at 75.

53 Boas, supra note 11, at 53. See also id. at 114-15.

54 Swadesh, supra note 18 , at 77,81 . Swadesh notes that Nootka warfare continued until about 1880 . Kwakiutl warfare ended by 1865 . Codere, supra note 1, at 112, 124 .

55 Swadesh supra note 18 , at 91.

56 Id. 
Following the decline of warfare and the rise of potlatching, the Kwakiutl were content to memorialize warfare in the winter dance ceremony in which costumed adversaries sang of the wars of their ancestors involving extensive bloodshed and the taking of property.

\section{E. Potlatching}

The word potlatch is said to derive from the Nootka language and means to give with the expectation of a return gift. ${ }^{57}$ The potlatch consisted of a ceremony arranged by a numaym or tribe, with its chief acting as host, for one or more guest groups. The guests were first given a lavish feast and then gifts, the value of which varied according to the recipient's social status. Potlatches were held for a variety of reasons, including important marriages, the birth of an heir to group titles, or the actual inheritance of those titles. They were also held to ransom war captives, to pay off would-be attackers, and to resolve title disputes to fishing and hunting territories. ${ }^{58}$ According to Drucker, another purpose of the potlatch was to validate the chief's claim to his group's ancestral privileges, names, and crests, which, as already noted, manifested the group's claim to specific fishing and hunting territories. ${ }^{59}$

Within the potlatch system of the Southern Kwakiutl there are said to have been exactly 658 named and numbered potlatch positions, with the number of the position indicating its holder's rank in Kwakiutl society. This ranking changed over time according to the participants' recent pot-

57 Boas, supra note 11 , at 51 .

58 According to Drucker, when title to land and fishing rights was in dispute, the claimants held what he calls a rivalry potlatch, described in the following passage: "When two chiefs claimed the same place, the first one would give a potlatch, stating his claim; then the second would try to outdo him. Finally, one or the other gave away or destroyed more property than his opponent could possibly equal. The one who had been surpassed had no recourse. $\mathrm{He}$ could no longer contest his claim, for, in the native mind, it came to be regarded as ridiculous that an individual of few resources (and of course this involved not only the man, but his entire local group) should attempt to make a claim against someone who had demonstrated power and wealth." Drucker, supra note 13, at 128 . The rivalry potlatch may be an example of the Coase Theorem at work. The winner of the rivalry potlatch was the most efficient resource manager and the highest valuing user of the territory whose title was under dispute. The potlatch gifts given by him to the loser served as compensation.

59 "The rights included those to names and titles, not only names of persons but traditionally owned names for houses and other property, the right to use specific masks and symbols in rituals, the right to perform the rituals themselves, to use carvings, feast dishes, and the ownership of places of economic and ritual importance. Feasts had a similar function. It was usual to announce to guests, for example, that they were invited to eat sockeye salmon from such-and-such a stream, which had been discovered, given to, or captured in war by an ancestor and transmitted to the incumbent head of the group. The public announcement and tacit recognition of the fact by the guest group, so to speak, legalized the claim." Id. at 56. 
latch performance. Each position holder was matched with one or more closely ranked rivals from other numayms or tribes with whom he competed in the distribution of potlatch gifts. The more generous the potlatch host at distributing gifts to his rivals, the greater his own and his group's social status. When the rival and his group reciprocated, if they failed to match their previous host's generosity, their potlatch ranking declined and the rank of their previous host increased. ${ }^{60}$ Competition between rivals for social status was intense, with each attempting to "live up to [his] position and maintain its greatness against a rival making an equally intense effort to challenge it."61

Early potlatch gifts included various skins, fur blankets, canoes, slaves, seals, and preserved meat or salmon. ${ }^{62}$ As the Kwakiutl gained access to trade and their wealth increased, the Hudson's Bay blanket became the most common potlatch gift, probably because of its durability and standardized character as a measure of value. Besides blankets other items were given as potlatch gifts, including silver bracelets, bolts of calico, copper engravings (called "coppers"), and even cash. ${ }^{63}$ Not only did the character of potlatch gifts change with the advent of trade, but the frequency and intensity of potlatching increased. For instance, between 1809 and 1849 it is estimated that approximately twenty-five potlatches were held each year, with around 200 blankets, several slaves, and two to four canoes given away in an average year. Between 1849 and 1941, on the other hand, as many as 12,000 Hudson's Bay blankets and 7,000 silver bracelets were given away in about forty different potlatches in an average year. ${ }^{64}$

Although potlatch property was most often transferred, there are a few accounts of destruction of property at potlatches. The goods destroyed were normally either canoes, coppers, or eulachen oil. The most significant account of destruction concerns a "grease feast" in which eulachen oil was poured on the fire by the participants (from both groups) in such large quantities that flames shot up to the rafters and burnt the

${ }^{60}$ The following passage, recorded several days before a great potlatch at the Kwakiutl village near Fort Rupert, indicates that potlatches were not always reciprocated: "O friends! Let me ask you chiefs and new chiefs of my tribe, do you wish to be laughed at by our rivals? We are almost beaten by the Koskimo. We are only one potlatch ahead of them. After this pile has been distributed, we shall only be two potlatches ahead of them, instead of four as our fathers used to be. Take care friends! Our friends the Koskimo are strong in rivalling us in distribution of property." Codere, supra note 1, at 119.

61 Id. at 66 .

62 Id. at $90-91$.

${ }^{63}$ Id.

${ }^{64}$ Id. 
roof of the lodge. Other accounts of property destruction involve the burning of canoes or the breaking of coppers and their disposal at the botton of the sea. The breaking of a copper, however, cannot be considered property destruction in a literal sense, since the value of the copper itself was low. The act is more akin to the destruction of a promissory note, as the copper represented the number of blankets its owner could demand at any time from the previous owner. In any event, actual property destruction at potlatches appears to have been fairly infrequent. ${ }^{65}$

\section{The Anthropological Hypotheses}

In this section I discuss two leading anthropological explanations of potlatching to be compared with and tested against my own. The first explanation, proposed by Codere in Fighting with Property, ${ }^{66}$ views potlatching as a substitute for warfare in the Kwakiutls' limitless pursuit of social prestige. Although this explanation is descriptively appealing, it completely lacks generality. The second explanation, proposed by Stuart Piddocke in The Potlatch System of the Southern Kwakiutl: A New Perspective ${ }^{67}$ views potlatching as a form of insurance against geographic variations in resource productivity that would otherwise have led to local starvation. By failing to recognize the structure of property rights as endogenous, however, Piddocke misidentifies the relevant constraints, and his explanation is therefore incomplete. In Section IV, I propose an explanation of potlatching that avoids the shortcomings of Piddock's explanation by recognizing the structure of property rights as endogenous. Like Piddocke's explanation, my explanation emphasizes the redistributive element in potlatching, but as a method of protecting private property rights by paying off would-be encroachers rather than purely as a form of insurance against local variations in resource productivity. Since encroachment was invariably met with violence, like Codere's explanation, my explanation views potlatching as a substitute for the violent conflict

\footnotetext{
65 But see John Baden, Richard Stroup, \& Walter Thurman, Myths, Admonitions and Rationality: The American Indian as Resource Manager, 19 Econ. Inquiry 132 (1981), who argue that the incidence of property destruction among the Kwakiutl increased as Kwakiutl wealth increased and the resources involved became less scarce. The mutual destruction of eulachen oil seems to fit this observation. It has been reported that the level of production of eulachen oil by the Kwakiutl affected its price. As price searchers, then, the Kwakiutl may have been able to increase their total receipts from eulachen oil sales by mutually confirmed destruction of some portion of their output.

${ }^{66}$ Codere, supra note 1.

${ }^{67}$ Piddocke, supra note 8.
} 
that would otherwise have occurred had private property rights not been recognized.

Codere finds the most significant feature of Kwakiutl life to have been "their limitless pursuit of a kind of social prestige which required continual proving to be established or maintained against rivals. . . " observes that the major shift in Kwakiutl culture was from a time when social prestige was attained primarily through success in warfare and head hunting to a time when social prestige was attained only through success in potlatching. Codere argues that the sanctions imposed on violence by Canadian authorities did not cause this shift (since it was already underway) but they certainly reinforced it. She concludes that potlatching was a kind of ceremonialized warfare with property that substituted for warfare with weapons. Codere gives no indication why the Kwakiutl desired social prestige, nor does she indicate why social prestige required success at either warfare or potlatching. In this sense her explanation is ad hoc; it cannot be generalized outside the limits of Kwakiutl culture.

In contrast to Codere, whose concern is with potlatching well into the contact period, Piddocke focuses on potlatching during the prehistoric and early contact period. According to Piddocke, during the earlier period geographic and intertemporal productivity variations were frequent due to "the failure of fish runs" or prolonged periods of bad weather that prevent fishing. ${ }^{69}$ Consequently, although the region supported a population larger than normal for hunting and gathering societies, the Kwakiutl "lived sufficiently close to the margins of subsistence so that variations in productivity which fell below normal could threaten parts of the population with famine and death from starvation."70 Since the hunting and fishing territories of the numayms of a tribe were often some distance apart, geographic variations in productivity led to a variance in numaym output around the tribal or social mean. Piddocke argues that by promoting food exchanges "from those groups enjoying a temporary surplus to those groups suffering a temporary deficit . . .," the potlatch performed "a very real prosurvival or subsistence function, serving to counter the effects of varying resource productivity." 71 Given the extensive system of trade among the Kwakiutl, Piddocke notes that the recipient of durable potlatch goods could exchange them for badly needed foodstuffs, or the

${ }^{68}$ Codere, supra note 1 , at 118.

69 Piddocke, supra note 8 , at 286.

${ }^{70}$ Id.

${ }^{71}$ Id. at 283 . 
owner of surplus foodstuffs desiring to hold a potlatch could exchange them for the necessary durable goods. ${ }^{72}$

Piddocke concedes that "surpluses above any conceivable need" probably did occur during the later contact period as per capita Kwakiutl wealth increased due to absolute population decline and the prolific trade in furs and other goods. These developments "ensured that the productivity of sea and land, variable or not, was more than ample to meet the survivors' needs." frequency and intensity of potlatching that accompanied the Kwakiutls' rising per capita wealth is consistent with his insurance explanation, since the increased wealth above subsistence needs was then freely available for potlatching.

To the contrary, the observed increase in the frequency and intensity of potlatching that accompanied rising per capita wealth is inconsistent with Piddocke's explanation of potlatching as a prosurvival form of insurance. As per capita wealth increased and became "more than ample for the survivors' needs," the risk-reducing value of marginal potlatch gifts would have declined. Therefore, if the purpose of potlatching was to insure against starvation, increased per capita wealth should have had no positive effect on the frequency and intensity of potlatching. ${ }^{74}$ The implications of Piddocke's explanation, then, are contrary to observed fact. Moreover, Piddocke's explanation can be criticized on theoretical grounds. The development of trade with the outside world was, in part, responsible for the Kwakiutls' rising per capita wealth; but increased trade opportunities also increased the Kwakiutls' ability to self-insure against yearly productivity variations by converting surplus foodstuffs in one year into durable goods and then reconverting those durable goods into foodstuffs in later years when output was low.

Most important, Piddocke fails to recognize that variations in numaym output were a direct result of the structure of property rights among the Kwakiutl. Had property rights in fishing and hunting territories been held in common rather than in private, local variations in productiv-

72 Id. at 296. The Kwakiutl apparently possessed well-developed capital markets, which numaym chiefs used to finance their potlatches. On declaring his intention to hold a potlatch, a chief often borrowed from members of his own numaym or tribe, with the obligation to repay the loan plus interest when he in turn was the recipient of potlatch gifts. It appears that a creditor was often unable to request repayment until he declared an intention to hold his own potlatch. E. Curtis, The Kwakiutl, in 10 E. Curtis, The North American Indian 144 (1915).

${ }^{73}$ Piddocke, supra note 8 , at 291.

74 Orans makes the same criticism of Piddocke but, apparently, for different reasons. See generally Orans, supra note 9. 
ity would have had little or no impact on each numaym's output, since the numaym experiencing low productivity could simply have migrated to an area where the salmon run was better. ${ }^{75}$ Under common property rights the output of each numaym would have been equal to the tribal or social mean year in and year out. Of course, with fishing rights held in common, the incentive for efficient resource management would have been lower, and the average yearly output of the numayms would have been less than under a system of private property rights, even though the variance in output across numayms would also have been lower. In the next part of this essay I recognize the structure of property rights as endogenous and develop my explanation of potlatching as an institution designed to protect private property rights in fishing and hunting territories.

\section{A Theory of Property Rights}

In this section I develop an explanation of potlatching based on the hypothesis of constrained wealth maximization. Wealth, of course, is defined as the net present value of all goods available through time for a decision maker's exclusive use; wealth is a stock concept including values both today and in the future. ${ }^{76}$ The wealth maximization hypothesis implies that individual decision makers will establish and enforce private property rights whenever doing so leads to a net increase in wealth. But private property rights are not costlessly enforced, and, since the essence of private property rights is the ability to exclude, the method of enforcement chosen will be that which minimizes the cost of assuring any given level of exclusivity. It follows that wealth-maximizing individuals will compete to establish exclusive claim to scarce resources. Competition can take a variety of forms, and the form of competition that ultimately prevails will determine the character of winners and losers in the final allocation of scarce resources. If competition takes the form of violence, resources will tend to flow toward those who are the strongest, the quickest to act, and the most ruthless, but also, within some narrow range, toward those whose time spent in peaceful activities is least productive; if, on the other hand, competition takes the form of willingness to transfer wealth to others, resources will tend to flow toward those whose time spent in peaceful activities is most productive. ${ }^{77}$

75 This, essentially, was the nomadic life-style of the Indians of the interior.

${ }^{76}$ Though this should seem obvious, failure to recognize it has led to no end of mischief. See generally D. Bruce Johnsen, Wealth Is Value, J. Legal Stud. (in press).

${ }^{77}$ For an excellent discussion of the richness of the term competition see John S. McGee, In Defense of Industrial Concentration 8-12 (1971). 
In the long run, the form of competition will affect the size of the stock of available goods. Since the rent-dissipation effects of violent competition are obvious, ${ }^{78}$ the general tendency has been to replace violence with some alternative form of competition through cooperation. Cooperative limitations on violence create what can be considered private property rights. Private property rights provide assurance to a resource holder that he can exclude others from using it under specific conditions, and that he is therefore able to formulate accurate expectations in deriving income from its use. Private property rights are essential to wealth maximization, since they increase the certainty that individuals will capture the distant returns on their socially productive investments and thereby increase their willingness to make those investments. As a result, the stock of available goods increases and both the individual and society are better off.

Application of the traditional tools of economic theory to the creation and allocation of property rights has recently been undertaken by Alchian, Cheung, Coase, Demsetz, North, and others, ${ }^{79}$ although Karl Marx probably was first to employ the property rights approach in economic theory. ${ }^{80}$ Marx saw the development of property rights institutions as inevitable in man's struggle to overcome nature. Accordingly, he viewed primitive societies as those lacking property rights institutions to foster production and exchange, and whose entire attention is therefore directed toward subsistence activities. Rather than trying to explain the emergence and change of property rights institutions, however, Marx focused on the human alienation and class struggle they create.

Marx's fundamental insight into the importance of property rights has been incorporated into a neoclassical theory of the state by Douglass North. ${ }^{81}$ North defines the state as an organization having comparative

${ }^{78}$ Except in cases such as boxing and bullfighting where violence, properly constrained, is valued for its own sake.

${ }^{79}$ See, for example, Armen Alchian, Corporate Management and Property Rights, in Economic Policy and the Regulation of Corporate Securities (Henry Manne ed. 1969); Steven N. S. Cheung, The Structure of a Contract and the Theory of a Non-exclusive Resource, 13 J. Law \& Econ. 49 (1970); R. H. Coase, The Problem of Social Cost, 3 J. Law \& Econ. 1 (1960); Harold Demsetz, Toward a Theory of Property Rights, 57 Am. Econ. Rev. Papers \& Proc. 347 (1967); Douglass C. North, Structure and Change in Economic History (1981); Terry L. Anderson \& P. J. Hill, The Evolution of Property Rights: A Study of the American West, $18 \mathrm{~J}$. Law \& Econ. 163 (1975); and John Umbeck, Might Makes Rights: A Theory of the Formation and Initial Distribution of Property Rights, 19 Econ. Inquiry 38 (1981).

${ }^{80}$ See Svetozar Pejovich, Towards an Economic Theory of the Creation and Specification of Property Rights, 30 Rev. Soc. Econ. 309 (1972).

${ }^{81}$ See generally North, supra note 79. 
advantage in violence extending over a given geographic area. The state uses its monopoly on violence to maximize its own wealth by establishing and enforcing the set of property rights that maximizes the present value of the monopoly rents it can collect (subject to constraints). In attempting to explain changes in the structure of property rights institutions over time, North incorporates ideology into his model. He argues that ideology is a constraint that binds the individual to the group and thus helps to overcome the free rider problem that would otherwise render attempts at large group action impotent and institutional change much more problematic. In tracing man's development through the First Economic Revolution, North argues that the transition from hunting and gathering to agricultural production required the development of property rights institutions to promote productivity gains. This development was aided by ideology as manifested in the customs and social mores of the developing societies. In the views of both Marx and North (and as I argue in the conclusion) the distinction between primitive and modern societies is based on the extent of private property rights to promote husbandry of the natural environment, rather than on the functional form of production, that is, hunting versus agriculture.

North's analysis is complemented by the work of Harold Demsetz on the emergence of private property rights in hunting and trapping lands among the Montagne Indians of Quebec. ${ }^{82}$ Demsetz shows that as the early eighteenth-century fur trade developed and the price of furs increased, the Montagnes shifted their fur-producing lands from common ownership to private ownership. Demsetz also notes that the most complete development of private lands exhibited an unmistakable geographic correlation with the earliest centers of the fur trade. Although Demsetz does not describe the mechanism by which the Montagnes established and enforced private property rights where only common property rights once prevailed, he does demonstrate that the geographic pattern of private property rights was consistent with the wealth maximization hypothesis.

In order to understand how private property rights led to husbandry of the natural environment of the Southern Kwakiutl, it is important to understand the nature of their primary investment opportunities. Not surprisingly, the Kwakiutls' primary investment opportunities derived from their most important capital asset and main source of wealth, the salmon fishery. Recall that the size of a given salmon run depended on the success of the parent generation at spawning and on the success

${ }^{82}$ See generally Demsetz, supra note 79. 
of the current generation at surviving until mature and capable of spawning. The factors that influenced success rates can be classified as either environmentally determined (exogenous) or man-made (endogenous). The most important man-made determinant of success rates was fishing pressure (that is, the number of salmon taken from the stream and thereby prevented from spawning) during the previous generation's migration upstream. A statistical regularity long since established by fisheries biologists, and no doubt known to succesful numaym chiefs (those with knowledge), is that as fishing effort increased, the sustainable yield (that is, the biomass of salmon that could be repeatedly harvested over successive generations) first increased, then reached a maximum, then declined. The optimal amount of fishing effort depended in part on the opportunity cost of labor and in part on the impact of fishing effort on future yields. Moreover, although the environmental determinants of the size of a salmon run were exogenous, their impact on future run size could be minimized by appropriate adjustments in fishing effort based on prevailing conditions. Such adjustments were critical to a numaym's success because they were probably contrary to natural inclinations. For example, when the run was small the tendency would have been to harvest a larger than normal share in order to avoid a current reduction in output below the yearly average, thus leaving relatively few salmon to spawn and procreate the next generation. A numaym chief's decision not to overfish and to manage the salmon fishery properly can therefore be seen as a wealth-maximizing investment in future generations of salmon. The numaym, then, at the direction of its chief, is best seen as a resource management unit rather than merely as a resource exploiting unit, optimally adjusting fishing effort to minimize yearly output variations and maximize numaym wealth. ${ }^{83}$

Had private property rights in the salmon fishery been costlessly enforced, a wealth-maximizing numaym would have supplied the optimal amount of fishing effort. At the other extreme, if the numaym had no mechanism to assure exclusive property rights over future generations of salmon, it would have underinvested by overfishing: any increase in future generations of salmon as an investment return to optimal fishing effort would have been common property and would not have accrued to the decision-making numaym. The numaym's wealth would thus have been less than under a system of exclusive property rights. Given a society of wealth-maximizing numayms, there was clearly an incentive to improve on the situation.

${ }^{83}$ E. Rostlund, Freshwater Fish and Fishing in Native North America 16-17 (1952), argues that Indian fishing prior to commercial fishing helped to optimize the salmon population. 
There were several methods available to the Southern Kwakiutl of assuring exclusive property rights. The least-cost method depended on the constraints they faced. One method of assuring exclusive property rights was a mutual agreement by the numayms not to encroach on one another's hunting and fishing territories. Under such a system, however, as one numaym experienced relatively low marginal productivity due to a poor salmon run, the cost to its members of encroaching on another numaym's territory fell in terms of the number of fish the encroachers could otherwise catch if they respected the agreement. Variations in the opportunity cost of encroachment due to geographic variations in productivity apparently led to encroachment during prehistoric and early contact times, prior to the development of potlatching. ${ }^{84}$ According to the war records, encroachment was invariably met with violence by the incumbent numayms, and, in some cases of course, the encroachers came with the intent to annihilate the incumbent numaym. Apparently, simple agreement between numayms to recognize private property rights was not enough.

A second method of enforcing private property rights was for one numaym to offer protection payments to another numaym whose marginal productivity was relatively low due to a poor salmon run. By doing so it increased the other numaym's opportunity cost of encroaching. The size of the necessary protection payment would have been roughly equal to the net gain anticipated by the would-be encroacher. Since the alternative method of enforcing exclusivity was violence-which used the real resources of both the encroacher and the incumbent-and since a system of violent enforcement would have reduced the willingness of numayms to make wealth-increasing investments for fear of not capturing the full investment return, the incumbent numaym would always have been able to make the necessary protection payment and still come out with larger wealth than otherwise.

Given that all numayms faced the possibility of a poor salmon run at some time, the encroachment problem was reciprocal. Consequently, the Southern Kwakiutl established potlatching as a reciprocal exchange sys-

\footnotetext{
${ }^{84}$ Even in the absence of productivity variations, there would always have been an incentive for the members of one numaym to encroach on another numaym's fishing territory. This is because, in optimally exploiting their territories, all numayms would have continued to supply fishing effort until the marginal product of labor was equal to the opportunity cost of labor. But the marginal product of labor to an encroacher would have equaled the average product of labor to the incumbent and been greater than the marginal product of labor to either the incumbent or to the encroacher in its own territory. This is because the encroacher would not have had to bear the reduction in catch experienced by the incumbent as a result of his actions. See generally Cheung, supra note 79 .
} 
tem between numayms to enforce private property rights by smoothing the intertemporal variations in the opportunity cost of encroachment. Unless those numayms whose productivity was relatively low were paid off through the potlatch system by those numayms whose productivity was relatively high, the system of reciprocally recognized private property rights would undoubtedly have broken down. ${ }^{85}$ Abstracting from differences in managerial talent, over the long run the wealth transfers through the potlatch system would approximately balance, but all numayms would experience absolute increases in wealth due to their increased willingness to invest in future generations of salmon.

The role of social prestige among the Southern Kwakiutl can now be clarified. In the desire to increase their social prestige, those numaym chiefs who were the best resource managers, being also the wealthiest members of Kwakiutl society, rose in the potlatch ranking. Competition between numaym chiefs to increase social prestige through success in potlatching not only served to protect private property rights but also brought productivity gains by encouraging the husbandry of the natural environment. Perhaps more important, the desire to attain social prestige served as an ideological constraint on those who would otherwise have free ridden on the system by holding few or meager potlatches, both because of the consequent reduction in social prestige and potlatch ranking they would have suffered, and because of the reduction in the value of return potlatch gifts they would have received.

In Section II, I noted three important influences on the Southern Kwakiutl of contact with European civilization. First, contact led to an increase in the value of the natural resources claimed by the various Kwakiutl numayms; second, it brought severe sanctions on warfare and violence by the Kwakiutl; and third, it resulted in an absolute decline in Kwakiutl population. These influences, being exogenous to Kwakiutl culture, provide the basis for generating refutable implications that provide a test of my hypothesis.

It is well documented in the historical record that potlatching was an alternative to violence in enforcing exclusive property rights. Drucker, one of the main opponents of so-called functional explanations of potlatching (which, of course, includes my own), claims the purpose of potlatching was merely to validate social rank and legitimize the claim to

\footnotetext{
${ }^{85}$ Potlatching may have served the additional function of providing an incentive for the rumayms within the potlatch system to assist in defending the territories of other numayms from outside aggressors. That Kwakiutl warfare was increasingly directed toward nonKwakiutl groups as European contact increased (and as potlatching developed) seems to support this notion. See text at note 53 supra.
} 
hereditary privileges and crests. ${ }^{86}$ My explanation of potlatching based on property rights protection is consistent with Drucker's claim, because, as already established, these hereditary privileges manifested the holder's exclusive right to exploit his ancestral fishing and hunting territories. In essence, a potlatch gift was the host numaym's way of demonstrating to its guests that productive use had been made of the lands accorded to it. The potlatch gifts also rewarded the guests for their accord. The alternative to such an accord was encroachment and violence. The following passage, recorded during a winter dance ceremony in 1895 , indicates that the Kwakiutl themselves viewed potlatching as an alternative to violence:

We used to fight with bows and arrows, with spears and guns. We robbed each other's blood. But now we fight with this here (pointing at the copper which he was holding in his hand), and if we have no coppers, we fight with canoes or blankets.

True is your word. . . . When I was young I have seen streams of blood shed in war. But since that time the white man came and stopped up that stream of blood with wealth. Now we are fighting with our wealth.

This time of fighting has passed. The fool dancer represents the warriors but we do not fight now with weapons: we fight with property. ${ }^{87}$

This passage also supports the notion that European contact was responsible for the decline in warfare and the increase in frequency and intensity of potlatching observed throughout the nineteenth century. It might appear, at first, that this trend was entirely caused by the severe sanctions placed on violence by Canadian authorities. But as Codere points out, this trend was already underway in the early contact period, prior to the time Canadian authority began to be felt.

According to my explanation of potlatching, the observed increase in the frequency and intensity of potlatching throughout the early contact period was the result of increased trade opportunities made available to the Southern Kwakiutl by European contact. With trade, the value of the natural resources held by the Kwakiutl increased. This increased both the value of establishing exclusive property rights in fishing and hunting territories, and the value of encroaching on these areas. It is impossible to say, a priori, whether the increase in the value of the Kwakiutls' natural resources would have led to an increase or a decrease in the "degree" of exclusive property rights. It necessarily follows, however, that total expenditures-whether on violence or potlatching-to protect exclusive property rights in fishing and hunting territories would have increased. Thus the observed increase in frequency and intensity of potlatching is

\footnotetext{
${ }^{86}$ Drucker, supra note 10 , at $56,60$.

${ }^{87}$ Codere, supra note 1, at 118-19.
} 
consistent within my explanation. Without knowing more about the relative costs of enforcing exclusive property rights between violence and potlatching, however, my explanation cannot predict whether the increase in the value of the Kwakiutls' natural environment would have resulted in any substitution between expenditures on violence and expenditures on potlatching to protect exclusive property rights.

The absolute population decline experienced by the Southern Kwakiutl following European contact has similarly ambiguous implications for the relative frequencies of violence and potlatching. Violence, however, was probably a relatively labor-intensive input in protecting exclusive property rights, because, in most cases, actual violence was met with retaliation-if only in defense-and both relied primarily on labor inputs. It follows that the effect of absolute population decline would have been a relative shift away from violence and toward potlatching, as was actually observed.

Needless to say, the severe sanctions imposed on violence by Canadian authorities increased the cost of violently enforcing exclusive property rights in fishing and hunting territories. If potlatching and violence were alternative methods of enforcing property rights, then Canadian sanctions on violence would have produced an unambiguous shift away from violence and toward more frequent potlatching: as trade increased the value of natural resources, larger and more frequent potlatch gifts would have to be given to counteract the increased cost of violently excluding others. ${ }^{88}$ By forestalling encroachment, potlatching did provide insurance against local variations in productivity, as Piddocke argues. But the relevant constraint was not, as Piddocke asserts, the desire to insure against local starvation by smoothing income streams; it was rather the desire to protect the structure of exclusive property rights, which was in turn the cause of local variations in productivity.

Some final evidence in support of my property rights protection explanation for potlatching comes from the ethnographic record of the Nootka Indians. As noted in Section II, the Nootka were more warlike than the other Indian groups of the north Pacific coast. They not only engaged in more frequent wars over fishing and hunting territories, but they also continued their warlike ways later into the contact period. Recall that the Nootka derived a large portion of their output from whaling off the west-

${ }^{88}$ All the available evidence indicates that Canadian authorities did not excuse violence as retaliation for trespass. The sanctions against violence thus increased the cost to an incumbent numaym of violently excluding encroachers. And since Canadian authorities did not protect property rights in fishing territories against Indian encroachment, the only reasonable method of assuring exclusivity was potlatching. 
ern coast of Vancouver Island. The high cost of establishing exclusive property rights in live whales may have increased the cost or reduced the benefit of potlatching to the Nootka, thereby leading them to place more reliance on violence as a means of protecting exclusive property rights. ${ }^{89}$

\section{Conclusion}

The pervasive use of reciprocity to regularize social relations in primitive societies has been frequently noted by anthropologists. It may be appropriate, however, to question whether the Southern Kwakiutl can truly be characterized as a primitive society. According to the definition of primitive society put forth by Marx and North they cannot, because they possessed a well-developed system of exclusive property rights. Unlike most primitive societies, the Southern Kwakiutl institutionalized their reciprocity relations through potlatching, which in my view was a substitute for the "state" in protecting exclusive property rights. Given the sophistication of potlatching as a property rights protecting institution, it is not surprising that among all North American Indians the Southern Kwakiutl realized an unsurpassed standard of living.

In comparing the extent of property rights in natural resources between the coastal Indians and the Indians of the interior-from whom the coastal Indians are believed to have descended-Boas observes:

However, the feeling of attachment to the home is strong all along the Pacific coast, far south into California, under the most diverse conditions of geographical environment and of food supply. In contrast to these, the tribes of the interior are much less firmly attached to the soil, each band having its own habitat; but the attachment of the individual to his band and also that of the band to its location was rather loose and liable to change, without particular reference to the more or less favorable food supply found in a central location. ${ }^{90}$

The unusual propensity of these coastal Indians for exclusive property rights no doubt emerged from the character of the salmon fishery (common to them all) and the technology available in exploiting it and protecting it from encroachment. Compared with the sources of wealth available to the Indians of the interior, such as buffalo and antelope, salmon-at least for some short period-stayed put in a closely confined space. Exclusive property rights in salmon were thus enforceable at relatively low cost. The development of exclusive property rights by the coastal Indians

\footnotetext{
89 As with sea otters, and unlike halibut, live whales probably do not stay put within a confined area. Thus establishing exclusive property rights in live whales, either through violence or potlatching, would have been difficult. Interestingly, the Nootka did recognize exclusive property rights in beached whales. See Swadesh, supra note 18 , at 85 .

${ }^{90}$ Boas, supra note 11 , at 47.
} 
allowed them to formulate accurate expectations concerning their use of scarce resources and thereby encouraged them to make wealth-increasing investments in the salmon fishery. The high population density of the coastal Indians during prehistoric and early contact times compared with the Indians of the interior seems consistent with this assertion.

I have argued in this essay that the Southern Kwakiutl Indians used the seemingly curious institution of potlatching to enforce exclusive property rights in the salmon fishery. By smoothing intertemporal variations in the opportunity cost of encroachment, potlatching forestalled the wasteful, violent conflict that would have otherwise occurred. As with modern-day organized exchange markets, potlatching directed the flow of resources toward relative scarcity and away from relative abundance. In this respect potlatching was completely rational and completely consistent with economic theory. 